\title{
Study on the Application of Experiential Teaching in Music Education in Colleges and Universities
}

\author{
Dandan Dai \\ Nanchang Vocational College, Nanchang, 330000
}

Keywords: music education in colleges and universities, Experiential Teaching, application

\begin{abstract}
With the continuous deepening and development of quality-oriented education, music education has been gradually promoted by colleges and universities in China in response to the call for quality education. Experiential teaching mode is entering into music classroom teaching with a brand-new form of education, and is favored by teachers and students. The application of experiential teaching in music teaching has a positive effect on the vigorous development of music education. At present, there are still many problems in the experiential teaching of music education. This paper mainly analyzes problems existing in experiential teaching of music in colleges and universities, and then puts forward relevant rationalization and optimization measures to promote the application of experiential teaching mode in music education, hoping to provide reference for music educators.
\end{abstract}

\section{Introduction}

Music, as an important discipline in colleges and universities, is a vital part of disciplines of higher education. Music plays an important role in the development of higher education. The Experiential Teaching targets students' experience, promotes students to innovate music theory knowledge continuously in the actual music learning, and helps them understand deeply and master music knowledge, thus making them enjoy music learning. The application of Experiential Teaching mode in music education not only improves students' enthusiasm for learning effectively, but also arouses their initiatives for learning. At the same time, it also effectively improves the quality of music teaching. Therefore, colleges and universities are supposed to attach great importance to Experiential Teaching and give full play to their role in music teaching so as to promote the sound development of music teaching.

\section{Problems Existing in the Traditional Music Teaching in Colleges and Universities at Present Stage}

At present, some colleges and universities in China lack perfect music teaching environment in the actual music teaching. There is still some improving space in music teaching infrastructure. Due to the lack of teaching equipment, students can not get musical instruments support, which leads to certain restriction to the development of music activities. In terms of music examination, colleges and universities lack substantive examination standards and norms, failing to test students' cognitive level of music. At the same time, for students, early music training is very important and for those who have never touched music, learning music is relatively difficult. Though some students are confident in learning music at the very beginning, because of their inferiority feeling and irony from classmates, they often quit music learning. Experiential Teaching requires the participation of students to play a real role. If students' participation in music teaching can not be promoted, the effects will be greatly reduced.

At present, students are more active in thinking, and are always curious about new things. However, in the traditional teaching of music education, contents of music classroom teaching are dull and boring. In addition, teaching methods of music teachers are too backward to meet the needs of the development of current music teaching. To some extent, these factors lead to the loss of students' interests in current classroom teaching. Meanwhile, in traditional music teaching, music 
teachers' complete self-dominant position ignores that students are actually the main body of teaching. In class, teachers are engaged in teaching for teaching, which is based entirely on their own wishes and teaching tasks, failing to play the subjective role of students. To a certain extent, it hinders the development of students' innovative thinking and leads to the overall decline in the efficiency of the whole class.

At present, students of colleges and universities come from different regions of the country. Because of the differences in their education and knowledge reserve, there is a difference in their ability to receive knowledge during music teaching. However, in the traditional music teaching in colleges and universities, teachers are totally dependent on the teaching syllabus, ignoring the differences among students. Besides, music teaching activities of music teachers are relatively monotonous, which hinder the smooth development of music teaching activities. In addition, teachers are negligent in the actual understanding of students, resulting in their inability to effectively know their teaching effects, thus leading to relatively low efficiency in classroom teaching.

\section{Importance of Experiential Teaching in Music Education in Colleges and Universities}

The application of Experiential Teaching in music teaching has greatly changed the way students learn. In the past study, students acquired knowledge mainly from the explanation of music teachers in the classroom. In the course of the whole music learning, students are completely in a passive position, receiving the instillation of knowledge from teachers. While, experiential learning theory explores students' autonomy, cooperation and inquiry, aiming to change their previous learning methods. In the course of music learning, students no longer passively absorb ready-made results in teaching materials in the traditional mode, but actively participate in rich practical teaching. Vivid thinking activities will improve students' understanding and mastery of music knowledge. In addition, in the course of experiential music teaching, music teachers are required to constantly improve students' active exploration spirit, strengthen their spirit of unity and cooperation, improve their consciousness of inquiry, and thus effectively change the way of students' learning.

Experiential learning theory emphasizes that education centers on students' practical ability and innovation spirit, which can effectively improve the theoretical innovation spirit of students. At present, compared with the traditional mode of music teaching, Experiential Teaching has more advantages in innovation and autonomy. Therefore, the advantages of experiential learning theory provide a solid foundation for cultivating innovative thinking and innovative ability of college students.

Under the current situation, music teaching in colleges and universities still adopts traditional teaching theories and teaching methods. Although music teaching in traditional mode attaches importance to students' music skills and aesthetic training, under normal circumstances, teachers often tend to focus on the teaching of music theoretical knowledge, ignoring the cultivation of students' practical ability. Students' practice of music only stays in the stage of mechanical imitation, and teachers do not give them extra time to practice, which leads to the overall low efficiency in the study of music. However, the application of Experiential Teaching in music teaching successfully solves problems mentioned above, and makes up for its shortcomings and defects. Experiential learning pays more attention to students' musical skills training, and emphasizes that an open, compatible and independent music teaching mode should be adopted in music teaching, so as to effectively improve the formation of students' music learning ability.

\section{Application of Experiential Teaching in Music Education in Colleges and Universities}

Experiential Teaching is basically the same as the traditional teaching mode, which requires a specific teaching environment. Compared with the traditional teaching mode, Experiential Teaching pays more attention to student-oriented teaching idea. In music teaching, students are the main body of class, who are actively accepting related music knowledge. Therefore, it is very necessary for music teachers to build an Experiential Teaching environment for students. For example, music 
teachers in the actual classroom teaching should create positively an emotion-orientated teaching situation. Through the creation of such music learning environment, students will be able to produce aesthetic feelings brought by the melody of music in the real music emotional environment and experience artistic charm of music education, so as to improve their aesthetic ability in music. Moreover, teachers are required to rationally design the contents of music teaching according to the actual characteristics of students, as well as integrate interactive teaching method into actual classroom teaching. Through emotional interaction between teachers and students, it is conducive to stimulating emotional experience of students to music. In addition, teachers are supposed to learn to use modern technology to create situational experience environment, make use of multimedia to create situations, and make students fully integrate into the emotional atmosphere of music. For example, when teaching music, teachers are suggested to ask students to get familiar with the creation background of each song in advance, and then make use of multimedia to display the creative background of songs to students in the form of videos. This kind of design of teaching situation not only inspires students' experience in creation, but also helps to enhance their emotional values.

At present, for students in colleges and universities, music is not a theoretical course, but a kind of emotional language that speaks of the heart as well as their most true emotional experience. Therefore, teachers in music teaching need to actively guide students to experience music art. Music is a relatively abstract art, so whether students can truly enter the world of music depends on students' real experience and perception, which is not determined by music teachers' exaggerated talk. Therefore, in the teaching of music, teachers are required to to adopt a variety of teaching methods, really attract students to the actual music learning, organically combine music teaching with students, guide them to experience music and understand the artistic beauty, so as to effectively enhance students' understanding and mastery of music knowledge. Teachers are supposed to make use of teaching activities to place students in teaching activities, so that students can improve the ability to learn music through experiencing, learning and understanding music. Besides, teachers are suggested to be good at getting rid of the constraints of traditional music teaching mode, strengthening friendly interaction with students, entering students' emotional world, listening to their true thoughts, truly understand their interests, and then effectively carry out music teaching as well as improve students' inner emotional expression.

In the teaching of music in colleges and universities, exploratory learning has been well received by people from all walks of life as well as favored by educators from colleges and universities. Therefore, music educators have integrated exploratory teaching into current music practical teaching, which has a feasible guiding significance for the development of music education in colleges and universities. Music teachers lead students to explore experience, which plays an important role in the development of music classroom teaching. In addition, in the actual classroom teaching, music teachers should actively provide students with music related teaching materials, positively create a good music learning atmosphere, and further strengthen the enthusiasm of students for music learning. In music class, teachers are advised to set up reasonable teaching problems according to the actual situation of music teaching, arrange students to carry out group cooperative learning and exploratory learning, thus effectively enhancing their ability to understand music. In a word, exploratory experience not only can stimulate students' interests in learning and arouse their enthusiasm for learning, but also exercise their innovative ability to a great extent.

\section{Conclusion}

To sum up, with the continuous deepening and development of China's education system reform, it has put forward higher requirements for music teaching in colleges and universities. Music teaching under the traditional mode has been unable to meet the needs of music education development. Current music teaching has seriously hampered students' music learning, greatly reducing the quality of music teaching. The application of Experiential Teaching in music education has successfully solved problems existing in the current teaching. Based on this, this paper mainly analyzes the application of Experiential Teaching in music teaching, and discusses the advantages 
of Experiential Teaching from three aspects, which respectively are situation creation experience, practical experience and exploratory experience, so as to effectively promote the continuous development of music teaching in colleges and universities.

\section{Acknowledgement}

The work was supported by the Topic of Nanchang Vocational College with the project number 2016-026 and the project name Research on the Reform and Practice of Music Curriculum System in Higher Vocational Colleges Based on the Promotion of Employability.

\section{References}

[1] Zhang Tingting. Application of Experiential Teaching in Music Education in Colleges and Universities [J]. Yellow River Voice, 2017, No.48104:33.

[2] Bao Yuzhu. Application of Experiential Teaching in Music Education in Colleges and Universities [J]. Contemporary Educational Practice and Teaching Research, 2015,12:162.

[3] Wang Dewei, Wang Xuemei. Analysis of the Application of Experiential Teaching in Music Education in Colleges and Universities [J]. Good Parents, 2017, No.52012:224.

[4] Chen Xiao. Application of Experiential Teaching in Music Teaching in Colleges and Universities [J]. Drama House, 2016, No.23014:207+213. 